\title{
Proteus mirabilis interkingdom swarming signals attract blow flies
}

\author{
Qun $\mathrm{Ma}^{1}$, Alicia Fonseca ${ }^{2}$, Wenqi $\mathrm{Liu}^{2}$, Andrew T Fields ${ }^{2}$, Meaghan L Pimsler ${ }^{2}$, \\ Aline F Spindola ${ }^{3}$, Aaron M Tarone ${ }^{2}$, Tawni L Crippen ${ }^{4}$, Jeffery K Tomberlin ${ }^{2}$ and \\ Thomas K Wood ${ }^{1}$ \\ ${ }^{1}$ Department of Chemical Engineering, Texas A \& M University, College Station, TX, USA; ${ }^{2}$ Department of \\ Entomology, Texas A \& M University, College Station, TX, USA ${ }^{3}$ Department of Agronomy, Universidade \\ Federal Rural de Pernambuca, Recife, Brazil and ${ }^{4}$ US Department of Agriculture, Agricultural Research \\ Service, Southern Plains Agricultural Research Center, College Station, TX, USA
}

\begin{abstract}
Flies transport specific bacteria with their larvae that provide a wider range of nutrients for those bacteria. Our hypothesis was that this symbiotic interaction may depend on interkingdom signaling. We obtained Proteus mirabilis from the salivary glands of the blow fly Lucilia sericata; this strain swarmed significantly and produced a strong odor that attracts blow flies. To identify the putative interkingdom signals for the bacterium and flies, we reasoned that as swarming is used by this bacterium to cover the food resource and requires bacterial signaling, the same bacterial signals used for swarming may be used to communicate with blow flies. Using transposon mutagenesis, we identified six novel genes for swarming (ureR, fis, hybG, zapB, fadE and PROSTU_03490), then, confirming our hypothesis, we discovered that fly attractants, lactic acid, phenol, $\mathrm{NaOH}, \mathrm{KOH}$ and ammonia, restore swarming for cells with the swarming mutations. Hence, compounds produced by the bacterium that attract flies also are utilized for swarming. In addition, bacteria with the swarming mutation rfaL attracted fewer blow flies and reduced the number of eggs laid by the flies. Therefore, we have identified several interkingdom signals between $\boldsymbol{P}$. mirabilis and blow flies.

The ISME Journal (2012) 6, 1356-1366; doi:10.1038/ismej.2011.210; published online 12 January 2012

Subject Category: microbe-microbe and microbe-host interactions

Keywords: interkingdom signal; Proteus mirabilis; Lucilia sericata; salivary gland; quorum sensing; bacterial swarming
\end{abstract}

\section{Introduction}

Bacteria consumed by immature blow flies feeding on a resource survive larval molting and pupation and are present in emergent adults; hence, resulting flies serve as a dispersal mechanism for the bacteria (Ahmad et al., 2006). Flies and their relatives disperse over 100 pathogens (Greenberg, 1973), many of which are responsible for the estimated 76 million food-borne illnesses occurring annually in the United States. These pathogens include Escherichia coli O157:H7, which is responsible for hemorrhagic colitis and hemolytic uremic syndrome (Sanderson et al., 2006) and accounts for 73000 illnesses and 61 deaths annually (FoodNet, June 2006). Thus, it is imperative to understand how bacterial pathogens are transported by insects.

Correspondence: TK Wood, Department of Chemical Engineering, Pennsylvania State University, State College, PA 16802, USA. E-mail: TWood@engr.psu.edu

or JK Tomberlin, Department of Entomology, Texax A \& M University, College Station, TX, USA.

E-mail: jktomberlin@tamu.edu

Received 2 October 2011; revised 5 December 2011; accepted 14 December 2011; published online 12 January 2012
Proteus is a genus of Gram-negative bacteria, many of which cause infections in humans (Liu, 2010), with Proteus mirabilis causing 90\% of these infections. It commonly inhabits dogs, cows and birds, and can cause nosocomial infections when colonizing human feces in hospital settings. Lucilia sericata (Diptera: Calliphoridae) is a common blow fly populating most areas of the world. It is typically one of the first organisms attracted by odors from cadaver decomposition (Clark et al., 2006). L. sericata larvae are also the primary species used for maggot therapy (Schmidtchen et al., 2003).

Blow flies are attracted and repelled by various factors, including temperature, light and odors, and flies sense and respond to attractants by receptors on legs, cerci and antennae (Dethier, 1947). Attractants help flies recognize potential mates and kin, oviposition (egg laying) sites and food sources. Repellents usually help protect insects from danger, such as predators. Proteins, fats and oils are the major materials of living organisms. Although these molecules themselves do not produce odor, their decomposition in carrion, feces, urine and animal secretions (that is, sweat, decomposing plant material, fungi and algae) are usually odorous (Dethier, 
1947). Among all the decomposition compounds from fats and proteins, ammonia appears to be the most common single nitrogenous product. It is a major constituent of urine, acting as a primary excretion product as well as a secondary product of urea decomposition. Skatole, indole, mercaptans and sulfides are the most penetrating odors of putrefaction. Another large group of attractants are fatty acids, which are usually fermentation products and decomposition components.

Quorum sensing (QS) is the regulation of gene expression in bacteria as a function of the concentration of secreted small molecules that reflect cell density (Miller and Bassler, 2001). Gram-positive and Gram-negative bacteria both use QS communication to regulate their behavior, including symbiosis, virulence, competence, conjugation, antibiotic production, motility, sporulation and biofilm formation (Davies et al., 1998; González Barrios et al., 2006). Acylhomoserine lactones in Gram-negative bacteria as well as indole, and autoinducer 2 in both Gram-negative and Grampositive bacteria (Jayaraman and Wood, 2008; Han et al., 2010) are typical QS signals. QS regulates swarming motility (Daniels et al., 2004).

Swarming is a flagella-driven movement of differentiated hyperflagellated, elongated and multinucleated swarmer cells by which bacteria spread as a biofilm over a surface (Daniels et al., 2004). Glycolipid or lipopeptide biosurfactants work as wetting agents by reducing surface tension. The QS signal acylhomoserine lactone enhances swarming motility in Serratia liquefaciens (Daniels et al., 2004), whereas indole diminishes Pseudomonas aeruginosa swarming motility (Lee et al., 2009). The quorum-quenching signal brominated furanone (Gram et al., 1996) inhibits E. coli swarming motility via inhibiting both acylhomoserine lactone- and autoinducer-2-mediated signaling (Ren et al., 2001).

Bacteria and fruit flies (Diptera: Drosophilidae) share a common cell-cell communication system (Waters and Bassler, 2005). The inner membrane protein AarA of Providencia stuartii is required for the release of an extracellular quorum-sensing signal whose structure has not been identified yet (Waters and Bassler, 2005). The homolog of AarA in the fruit fly Drosophila melanogaster is a rhomboid protein RHO that controls fly wing vein development and eye organization. Expression of $P$. stuartii aarA in a $D$. melanogaster rho mutant rescued wing vein development, whereas expression of rho in a $P$. stuartii aarA mutant complemented the QS signaling defect.

Interkingdom signals can help bacteria recognize the host immune system (Hughes and Sperandio, 2008). For example, the P. aeruginosa OprF protein on the cell surface binds to interferon- $\gamma$ from the host, activates the QS system by inducing rhlI (RhlI synthesizes the QS signaling molecule $\mathrm{C}_{4}$ homoserine lactone), induces the expression of lecA (encodes virulence determinant type I $P$. aeruginosa lectin (PA-I lectin)) and increases the production of pyocyanin (Wu et al., 2005). P. aeruginosa also detects adenosine of injured host cells and activates its PA-1 lectin virulence factor (Patel et al., 2007). Furthermore, indole works as a beneficial signal in intestinal epithelial cells by increasing epithelialcell tight-junction resistance and attenuating inflammation indicators (Bansal et al., 2010).

The rationale for the work here is that as flies respond to compounds produced by bacteria and as bacteria use signals to swarm, we hypothesized that bacterial strains deficient in swarming signals may also be deficient in interkingdom signaling with flies. After generating $P$. mirabilis transposon mutants that were deficient in swarming, we tested 10 compounds that attract flies (Table 1) for their ability to restore swarming and to restore interkingdom signaling between $P$. mirabilis and L. sericata. Using this approach, we identified five new chemicals (fly attractants) that are related to swarming, identified six new swarming pathways related to the synthesis of these compounds and determined part of genetic basis for the interkingdom signaling.

\section{Materials and methods}

Bacterial growth P. mirabilis from the maggot salivary gland was routinely grown in Luria-Bertani medium at $37^{\circ} \mathrm{C}$. For the plate competition experiments, E. coli BW25113 wild-type (Baba et al., 2006) and $P$. aeruginosa PA14 wild-type (Liberati et al., 2006) were utilized.

\section{Maggot salivary gland extraction}

L. sericata larvae were grown at room temperature on beef liver in jars until the third instar. Individual larvae with full crops were removed their containers and quickly rinsed in diluted bleach solution (1.25\% sodium hypochlorite), followed by two phosphate-buffered saline solutions $(0.8 \% \mathrm{NaCl}$, $0.02 \% \mathrm{KCl}, 0.144 \% \mathrm{Na}_{2} \mathrm{HPO}_{4}$ and $0.024 \% \mathrm{KH}_{2} \mathrm{PO}_{4}$, $\mathrm{pH}$ 7.4) before dissection. The salivary gland was removed and put into a sterile microcentrifuge tube filled with sterile phosphate-buffered saline $(20 \mu \mathrm{l}$ per pair of salivary glands to be extracted).

\section{P. mirabilis identification}

The harvested glands were mashed and spread on trypticase soy agar plates with 5\% sheep blood (TS-blood agar; BVA Scientific, San Antonio, TX, USA). Plates were incubated aerobically for $24 \mathrm{~h}$ at $37^{\circ} \mathrm{C}$. Phenotypically distinct colonies were chosen and subcultured repeatedly onto fresh media to attain cultural purity. P. mirabilis was initially identified using API Rapid 20E manual identification test strips for Enterobacteriaceae (bioMérieux Inc., Marcy l'Etoile, France) using 20 biochemical tests, including glucose acidification, sucrose acidification, $\beta$-galactosidase and indole production (Izard et al., 1984). 
Table 1 List of blow fly attractants used to complement the swarming of the Proteus mirabilis transposon mutants

\begin{tabular}{|c|c|c|c|}
\hline Attractant & Insect & Concentration in bacteria & Concentration used to attract flies \\
\hline Indole & $\begin{array}{l}\text { Lucilia Sericata (Dethier, } \\
\text { 1947) }\end{array}$ & $\begin{array}{l}\text { Escherichia coli: } 0.0703 \mathrm{mg} \mathrm{ml}^{-1} \\
\text { (extracellular) and } 0.0234 \mathrm{mg} \mathrm{ml}^{-1} \\
\text { (intracellular) (Domka et al., 2006). }\end{array}$ & $\begin{array}{l}\text { With 2-mercaptoethanol and sodium sulfide: } \\
\text { 10-100 } \mathrm{mg} \mathrm{ml}^{-1} \text {, and swormlure-2: } 41 \mathrm{mg} \mathrm{ml}^{-1} \\
\text { (Urech et al., 2004) }\end{array}$ \\
\hline $\begin{array}{l}\text { Sodium } \\
\text { hydroxide }\end{array}$ & L. cuprina (Dethier, 1947) & NA & $\begin{array}{l}\text { Water: } 200 \mathrm{mg} \mathrm{ml}^{-1} \text { (Hepburn and Nolte, } \\
1943)^{\mathrm{a}}\end{array}$ \\
\hline $\begin{array}{l}\text { Potassium } \\
\text { hydroxide }\end{array}$ & L. cuprina (Dethier, 1947) & NA & $\begin{array}{l}\text { Water: } 7.2-240 \mathrm{mg} \mathrm{ml}^{-1} \text { (Hepburn and Nolte, } \\
\text { 1943) }\end{array}$ \\
\hline Lactic acid & $\begin{array}{l}\text { L. sericata, Calliphora } \\
\text { erythrocephala (Dethier, } \\
\text { 1947) }\end{array}$ & $\begin{array}{l}\text { Lactobacillus acidophilus: 0.07- } \\
0.7 \mathrm{mg} \mathrm{ml}^{-1} \text { (Juárez Tomás et al., 2003) }\end{array}$ & $\begin{array}{l}\text { A total amount of } 0.023-0.133 \mathrm{mg} \mathrm{h}^{-1} \text { from } \\
\text { human hands is attractive to mosquitoes } \\
\text { Aedes aegypti (Smith et al., 1970) }\end{array}$ \\
\hline Ammonia & $\begin{array}{l}\text { L. sericata (Hilker and } \\
\text { Meiners, 2002) }\end{array}$ & $\begin{array}{l}\text { P. mirabilis: } 0.297 \mathrm{mg} \mathrm{ml}^{-1} \text { (Vince et al., } \\
\text { 1973) }\end{array}$ & Ammonium hydroxide: 5\% (Cragg, 1950) \\
\hline Putrescine & Calliphoridae (Wardle, 1921) & $\begin{array}{l}\text { P. mirabilis: } 0.003-0.088 \mathrm{mg} \mathrm{ml}^{-1} \\
\text { (Sturgill and Rather, 2004) }\end{array}$ & $\begin{array}{l}\text { Water on filter paper: } 0.001-1 \mathrm{mg} \mathrm{ml}^{-1} \\
\text { (Robacker, 2001), } 1 \mu \mathrm{g} \text { attracts } 70 \% \mathrm{~L} \text {. sericata } \\
\text { (this study) }\end{array}$ \\
\hline$p$-Cresol & $\begin{array}{l}\text { Cochliomyia, Chrysomya } \\
\text { (Hilker and Meiners, 2002) }\end{array}$ & $\begin{array}{l}\text { Lactobacillus spp.: } 0.8 \mathrm{mg} \mathrm{ml}^{-1} \text { in } \\
\text { (Yokoyama and Carlson, 1981) }\end{array}$ & $\begin{array}{l}\text { A total amount of } 0.005-0.02 \mathrm{mg} \mathrm{ml}^{-1} \text { used to } \\
\text { attract mosquitoes (Culex quinquefasciatus) } \\
\text { for oviposition (Poonam et al., 2002) }\end{array}$ \\
\hline Benzoic acid & $\begin{array}{l}\text { Cochliomyia, Chrysomya } \\
\text { (Hilker and Meiners, 2002) }\end{array}$ & NA & Swormlure-2: $41 \mathrm{mg} \mathrm{ml}^{-1}$ (Urech et al., 2004) \\
\hline Butyric acid & Cochliomyia (Broce, 1980) & $\begin{array}{l}\text { Pig cecal bacteria: } 0.053-1.057 \mathrm{mg} \mathrm{ml}^{-1} \\
\text { (Kobayashi and Sakata, 2006) }\end{array}$ & $\begin{array}{l}\text { A total amount of } 0.02 \mathrm{mg} \mathrm{ml}^{-1} \text { used as a } \\
\text { synthetic fly attractant for Fannia femoralis } \\
\text { (Mulla et al., 1984) }\end{array}$ \\
\hline Phenol & $\begin{array}{l}\text { Cochliomyia, Chrysomya } \\
\text { (Hilker and Meiners, 2002) }\end{array}$ & $\begin{array}{l}\text { Marine bacteria: } 0.1-1 \mathrm{mg} \mathrm{ml}^{-1} \\
\text { (Updegraff, 1949) }\end{array}$ & $\begin{array}{l}\text { Swormlure-2: } 41 \mathrm{mg} \mathrm{ml}^{-1} \text { used in (Urech } \\
\text { et al., 2004) }\end{array}$ \\
\hline
\end{tabular}

Abbreviation: NA, not applicable.

aThe chemical concentrations for sodium hydroxide and potassium hydroxide used for fly attraction in Hepburn and Nolte (1943) were too high for bacterial growth, hence a smaller concentration was used.

${ }^{\mathrm{b}}$ Chemical concentrations for mosquito attractions are provided here due to the absence of information for fly attraction.

Sequencing of the gene for $16 \mathrm{~S}$ ribosomal RNA was also used to confirm the identity of $P$. mirabilis; shortread sequence products of $\sim 300 \mathrm{bp}$ length were produced with forward primer 5'-ACTTAACCCAAC ATCTCACGA- $3^{\prime}$ and reverse primer $5^{\prime}$-AGGATTAGA TACCCTGGTAGT-3' (Campbell et al., 1995), and long-read sequence products of $\sim 750 \mathrm{bp}$ length were produced using forward primer 5'-ACTCCTACG GGAGGCAGCAG-3' (Moreno et al., 2011) and the same reverse primer. Purified PCR products were sequenced in both directions, with a minimum of $2 \times$ coverage using standard BigDye-terminator Cycle Sequencing (Applied Biosystems Inc., Carlsbad, CA, USA) protocols and submitted to GenBank (JN790943 for P. mirabilis and JN790944 for Providencia spp.). The species identification of the bacterial strain was determined by comparing the consensus sequence against published 16S recombinant DNA sequences deposited in the GenBank Nucleotide Collection (nr/ nt) by utilizing the "blastn" algorithm of the Basic Local Alignment Search Tool (BLAST; NCBI, http:// www.ncbi.nlm.nih.gov).

Transposon mutagenesis and swarming-based screening

Transposon mutagenesis was performed with the EX-Tn5 < DHFR-1> Tnp transposome kit (Epicentre, Madison, WI, USA). After electroporation with $50 \mu \mathrm{l}$ of competent cells and $1 \mu \mathrm{l}$ transposome supplied by the kit, we obtained around 3000 colonies with the Tn 5 transposon randomly inserted in the genome. Mueller-Hinton agar plates (Atlas, 2004) were used to select mutants with transposons inserted using $10 \mu \mathrm{g} / \mathrm{ml}$ trimethoprim. The agar concentration was adjusted to $3 \%$ to prevent swarming during this step. We then screened 3000 colonies for swarming motility after $\sim 4 \mathrm{~h}$ on LuriaBertani agar plates with $1.5 \%$ agar at $37^{\circ} \mathrm{C}$. Fifty mutants with at least threefold decreased swarming were selected and confirmed as swarming-deficient strains using the same conditions.

\section{DNA sequencing to identify transposon insertion positions}

Genomic DNA was isolated from the swarming mutants via the UltraClean Microbial DNA isolation kit (MO BIO, Carlsbad, CA, USA). For sequencing, arbitrary PCR (Ueda and Wood, 2009) was performed; the first round of arbitrary PCR reaction (PCR1) was performed using $100 \mathrm{ng}$ of genomic DNA and arbitrary primer 1 (5'-GGCCAGGCCTGCAGAT GATGNNNNNNNNNNGTAT-3') along with internal specific primer (5'-ACGGATTCGCAAACCTGTCAC G-3'). The second arbitrary PCR reaction (PCR2) was performed with the PCR1 product and arbitrary primer 2 (5'-GGCCAGGCCTGCAGATGATG-3') along with external specific primer I (5'-AGGTGGCGGAA ACATTGGATG-3'). The third arbitrary PCR reaction 
was performed with the PCR2 product and arbitrary primer 2 (5'-GGCCAGGCCTGCAGATGATG-3') along with external specific primer II (5'-GGCGGAAACAT TGGATGCGG-3'). The final PCR product after three sets of arbitrary PCR was purified and sequenced using external specific primer II. NCBI BLAST was used to compare sequences and identify the transposon insertion site.

\section{Swarming complementation}

For the swarming complementation test, $10 \mu \mathrm{g} \mathrm{ml}^{-1}$ and $250 \mu \mathrm{g} \mathrm{ml}^{-1}$ of each chemical were added to Luria-Bertani agar plates $(1.5 \%$ agar). The stock solutions of indole and benzoic acid were dissolved in dimethylformamide, and $p$-cresol was dissolved in ethanol. The other chemicals (phenol, butyric acid, lactic acid, $\mathrm{NaOH}, \mathrm{KOH}$ and putrescine) were dissolved in $\mathrm{H}_{2} \mathrm{O}$. A volume of $2 \mu \mathrm{l}$ of exponentialphase cultures (OD $600 \sim 1.0$ ) were added to the surface of the agar plates and incubated at $37^{\circ} \mathrm{C}$. For the swarming complementation test with ammonia, $2 \mu \mathrm{l}$ and $15 \mu \mathrm{l}$ ammonium hydroxide were dropped on the lid of Petri dishes because ammonium hydroxide can easily release ammonia, and the evaporated ammonia can be sensed by bacteria in this way. Swarming halos were measured after $10 \mathrm{~h}$.

\section{Fly attraction and oviposition assay}

Flies from Davis (CA, USA) (Tarone et al., 2011) were maintained in $30 \mathrm{~cm}^{3}$ cages (BioQuip Products, Rancho Dominguez, CA, USA) and fed granulated sugar and water ad libitum. Emergent flies were fed blood collected from fresh cow liver for the first 4 days post emergence using cotton. Flies were tested at age 5-7 days, and cages were dried for $24-48 \mathrm{~h}$ between experiments after cleaning.

The fly attraction assay was performed at $21^{\circ} \mathrm{C}$ as shown in Figure 1a. Two- to three-hundred 7-day-old, blood-fed L. sericata blow flies were placed into the clean plexiglas olfactory testing cube we constructed $\left(45 \mathrm{~cm}^{3}\right)$ without food or water. Agar plates $(17 \times 100 \mathrm{~mm})$ with $P$. mirabilis cultures $\left(100 \mu \mathrm{l}, 10^{7} \mathrm{CFU} \mathrm{ml}{ }^{-1}\right.$ bacteria spread onto plates and incubated at $37^{\circ} \mathrm{C}$ for $24 \mathrm{~h}$ ) were put into the ends of each of the two tunnels (white, $10 \mathrm{~cm}$ in diameter, by $15 \mathrm{~cm}$ length PVC pipe; Charlotte Pipe, Charlotte, NC, USA), which were attached on opposite sides of the cube. The proximal end of the pipe was capped with an inverted funnel, thus allowing flies to enter but making it difficult from them to leave. A nylon screen within the tunnel prevented the flies from reaching the bacterial plates, while allowing odors to pass through. Flies were allowed to roam freely within the testing box for $24 \mathrm{~h}$. Two sticky traps (Bell Laboratories Inc., Chicago, IL, USA) lined the sides at the entrance to the tunnel to catch the flies entering the tunnel that were attracted to odor emitted from the bacterial plate. The flies captured within the tunnels on the sticky traps and the flies remaining within the testing cube were collected after $24 \mathrm{~h}$ and counted, and their sex and gravidity was assessed. The plexiglas cage and all components were washed
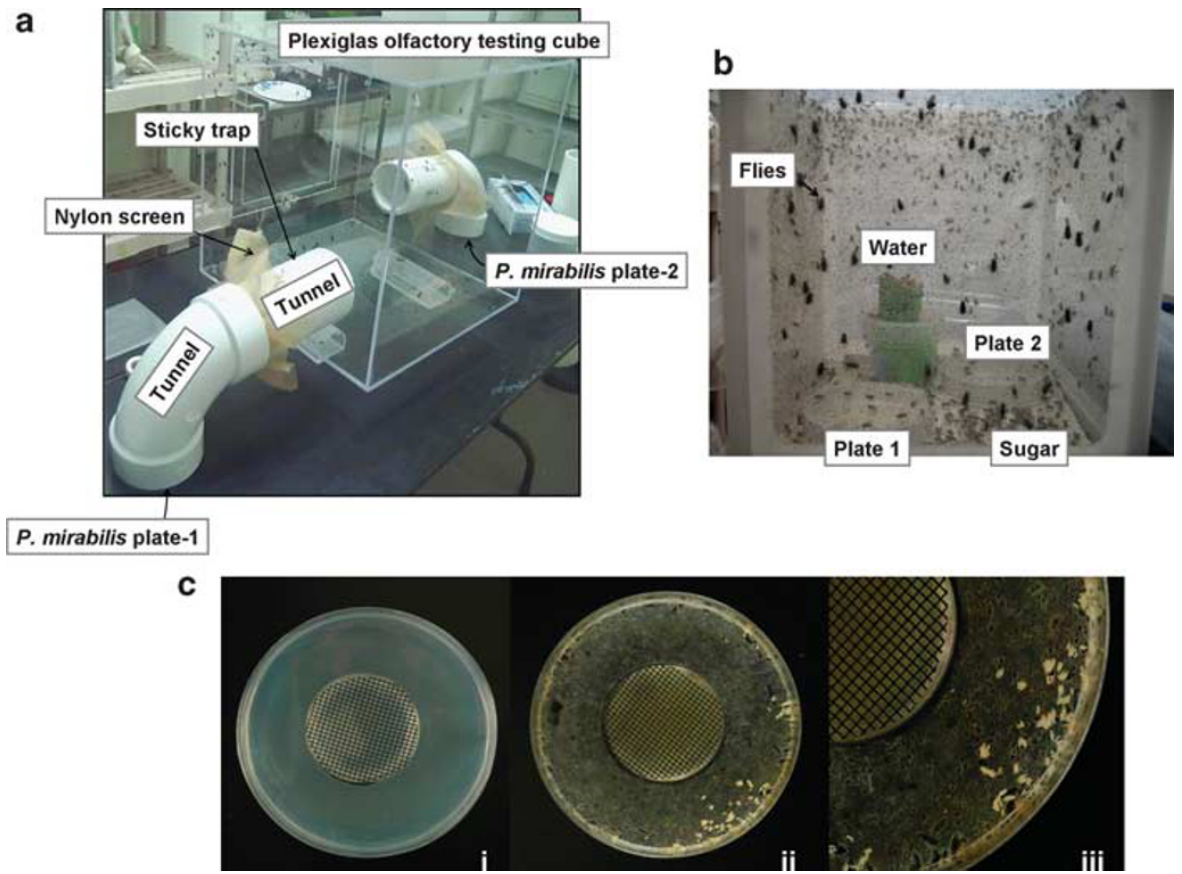

Figure 1 Apparatus for fly attraction assay (a) and fly oviposition assay (b), and plate details for the fly oviposition assay (c). (ci) For the fly oviposition assay, small agar plates $(35 \times 10 \mathrm{~mm})$ were plated with bacteria, covered with a nylon screen and placed in the center of larger $(17 \times 100)$ Luria agar plates. (cii) Screen allows volatile emissions, but experimental bacteria are inaccessible to direct contact by flies. (ciii) Eggs deposited on agar after $24 \mathrm{~h}$ at $23^{\circ} \mathrm{C}$. 
with odorless soap and dried before use in future replicates.

The oviposition assay was performed at $21^{\circ} \mathrm{C}$ using the system shown in Figure 1b. One- to twohundred 7-day-old, blood-fed L. sericata adults were placed in a mesh-covered cage with water and sugar provided ad libitum (Wal-Mart, Bentonville, AR, USA). Small Luria agar plates $(10 \times 35 \mathrm{~mm}$; USA Scientific Inc., Ocala, FL, USA) were inoculated with $13 \mu \mathrm{l}$ of $10^{7} \mathrm{CFU} \mathrm{ml}^{-1}$ bacteria, incubated for $24 \mathrm{~h}$ at $37^{\circ} \mathrm{C}$, covered with a plastic screen and sterilely placed in the center of Luria agar plates $17 \times 100 \mathrm{~mm}$ (USA Scientific Inc.; Figure 1c). Two sets of plates (wild type and mutant) were put inside the cage, and the flies were allowed to lay eggs on the Luria agar ring surrounding the centrally placed, small plates with the bacteria. Plates were collected after $24 \mathrm{~h}$ and eggs were counted. Cages containing flies were considered replicates and used only once. The heterogeneity $G$ test was used to analyze resulting adult blow fly attraction and oviposition data. This approach allowed us to determine whether expected values of response differed from the overall and pooled $\left(G_{\mathrm{p}}\right)$ observations, and to determine whether the level of variance and resulting ratio of responses differed across replicates (Sokal and Rohlf, 1995). Furthermore, this approach also was selected over calculating $\chi^{2}$-values, which are not additive and are only approximately correct. Resulting $G$ values are additive and correct, thus reducing the likelihood of type one error (Sokal and Rohlf, 1995).

\section{Fly responses to chemicals}

The behavioral response of 7-day-old $L$. sericata adults to either 1 or $10 \mu \mathrm{g}$ of putrescine paired with a blank control was measured in an olfactometer using methods similar to that of Margolies et al. (1997).

\section{Results}

Our hypothesis was that bacteria on decaying resources attract $L$. sericata to the carcass with signals that are related to bacterial swarming. To identify the biochemicals related to this interkingdom signaling, we isolated bacteria from flies, to obtain environmentally-relevant biological samples, then mutated the bacteria and screened for reduced swarming behavior. We determined whether bacterial metabolites that are known to be fly attractants could restore the reduced swarming behavior, thereby linking fly attraction with swarming. Finally, we tested the rfaL swarming mutant for differential olfactory and oviposition responses by the flies.

\section{P. mirabilis isolated from fly salivary glands}

By adding $L$. sericata maggot salivary gland extracts to E. coli and P. aeruginosa cultures, we found that one bacterium from the flies had notable swarming motility that outcompeted that of both E. coli and

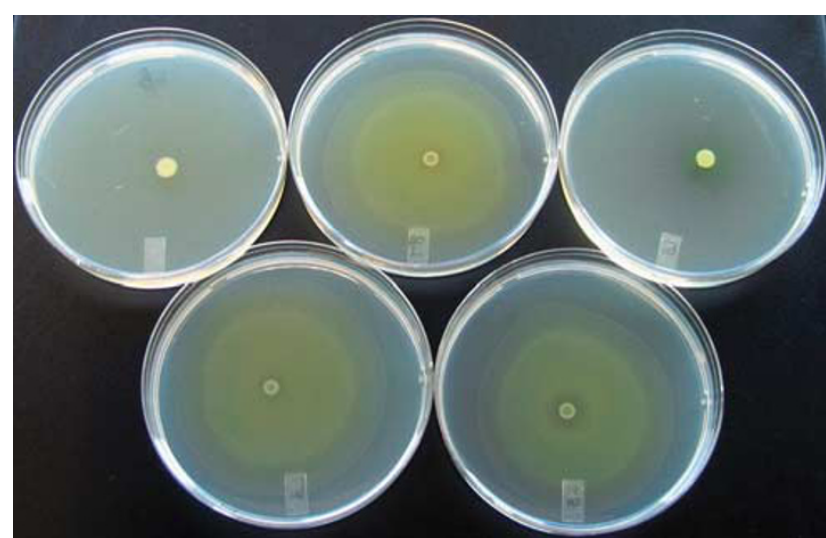

Figure 2 P. mirabilis outcompetes $E$. coli and $P$. aeruginosa with its swarming motility on Luria-Bertani (LB) plates. Cultures ( $5 \mu \mathrm{l}$ at a turbidity of 5 at $600 \mathrm{~nm}$ ) of each strain were loaded to the top of LB agar plates and incubated at $37^{\circ} \mathrm{C}$ for $18 \mathrm{~h}$ before taking pictures. Top row from left: E. coli, P. mirabilis, and P. aeruginosa. Bottom row from left: E. coli + P. mirabilis and P. aeruginosa+ P. mirabilis.

$P$. aeruginosa (Figure 2). This bacterium was identified as $P$. mirabilis $(100 \%$ match of a $660 \mathrm{bp}$ fragment) using both a biochemical characterization and Sanger sequencing of the bacterial $16 \mathrm{~S}$ ribosomal gene sequence. Another primary bacterium from the glands was identified as Providencia spp. (99\% match of a $668 \mathrm{bp}$ fragment). It was expected to find bacteria intimately associated with flies, as Providencia spp., E. coli O157:H7, Enterococcus faecalis (Orla-Jensen) and Ochrobactrum spp., have been previously isolated from the screwworm fly Cochliomyia macellaria (Ahmad et al., 2006). $P$. mirabilis has also been isolated from maggots of the blow fly Calliphora vicina (Erdmann, 1987).

\section{Swarming-deficient mutants}

After randomly mutating $P$. mirabilis, 3000 colonies were obtained, and 50 swarming-deficient mutants were identified. After confirming the swarming phenotype, 23 mutations were sequenced to identify which genes were related to swarming in $P$. mirabilis. Six groups of genes were identified (Table 2), including genes related to metabolism (hybG, proC, $p d x A$, adhE and fadE), regulation (fis, PMI2857 and yojN), transcription/translation (PMIr001, pnp, rhlB, rpsM, rrfG, ugd and ureR), cell surface ( $r f a L$ and zapB), flagella (flgK and flhD) and uncharacterized functions (PROSTU_03490). Four of these genes ( $r f a L, f l h D$, flgK and zapB) were previously identified to be related to swarming motility; hence, our method was able to recover some known swarming-related mutations for $P$. mirabilis. The flgK gene encodes the flagellar hook-associated proteins and is tightly associated with bacterial swarming motility (Fraser et al., 1999). The flhDC activator is the central component for regulating swarmer cell differentiation in P. mirabilis and other bacteria (Clemmer and Rather, 2007), and flhDC mutants are unable to swarm. 
Table 2 Summary of sequencing results for the Proteus mirabilis transposon mutants

\begin{tabular}{|c|c|c|c|}
\hline Mutation & Insert & Organism & Gene function \\
\hline \multicolumn{4}{|l|}{ Metabolism } \\
\hline hybG & Middle & P. mirabilis HI4320 & Hydrogenase nickel incorporation protein \\
\hline proC & Middle & P. mirabilis HI4320 & Pyrroline-5-carboxylate reductase \\
\hline$p d x A$ & Upstream & P. mirabilis HI4320 & 4-Hydroxythreonine-4-phosphate dehydrogenase \\
\hline adhE & Middle & P. mirabilis HI 4320 & Bifunctional acetaldehyde-CoA/alcohol dehydrogenase \\
\hline fadE & Middle & P. mirabilis HI4320 & Acyl-CoA dehydrogenase \\
\hline \multicolumn{4}{|l|}{ Regulator } \\
\hline fis & Middle & P. mirabilis HI4320 & DNA-binding protein Fis \\
\hline PMI2857 & Middle & P. mirabilis HI4320 & Helix-turn-helix XRE-family-like proteins \\
\hline yojN & Middle & Providencia rettgeri DSM 1131 & Putative two-component sensor protein such as YojN \\
\hline \multicolumn{4}{|l|}{ Nucleotide related } \\
\hline PMIr001 & Middle & P. mirabilis HI4320 & $16 \mathrm{~S}$ ribosomal RNA \\
\hline pnp & Middle & P. mirabilis HI4320 & Polynucleotide phosphorylase/polyadenylase \\
\hline rhlB & Middle & P. mirabilis HI4320 & ATP-dependent RNA helicase \\
\hline rpsM & Upstream & P. mirabilis HI4320 & $30 S$ ribosomal protein $\mathrm{S} 13$ \\
\hline $\operatorname{rrfG}$ & Middle & P. mirabilis HI4320 & dTDP-D-glucose-4,6-dehydratase \\
\hline ugd & Middle & P. mirabilis HI4320 & UDP-glucose 6-dehydrogenase \\
\hline ureR & Middle & P. mirabilis HI 4320 & Urease operon transcriptional activator \\
\hline \multicolumn{4}{|l|}{ Cell surface related } \\
\hline$r f a L$ & Middle & P. mirabilis HI4320 & O-antigen ligase \\
\hline$z a p B$ & Middle & P. mirabilis HI 4320 & Cell division protein \\
\hline \multicolumn{4}{|l|}{ Others } \\
\hline PROSTU_03490 & Middle & P. stuartii ATCC 25827 & Hypothetical protein \\
\hline \multicolumn{4}{|l|}{ Flagellar } \\
\hline$f \lg K$ & Middle & P. mirabilis HI4320 & Flagellar hook-associated protein 1 \\
\hline flhD & Upstream & P. mirabilis HI4320 & Transcriptional activator FlhD for flagellar \\
\hline
\end{tabular}

Abbreviation: BLAST, Basic Local Alignment Search Tool.

The transposon insertion site and the relative insertion position are listed (middle indicates that the transposon is inserted in the coding portion of the gene and upstream indicates that the transposon is inserted in the upstream intergenic region). The organism used for BLAST is also listed. P. mirabilis HI4320 is the best fit organism for the sequence BLAST. Providencia strains were also used for the BLAST search, as these two bacteria were co-isolated from Lucilia sericata.

In P. mirabilis, the ZapA protein (immunoglobulin A-degrading metalloprotease) works as a virulence factor expressed specifically in swarmer cells, although the zapA mutant does not show decreased swarming (Walker et al., 1999). The zapB gene that we identified is necessary for ZapA activity (Walker et al., 1999).

Complementation of swarming mutations via known fly attractants

To determine whether any of the swarming mutations are part of interkingdom signaling with blow flies, 10 known blow fly attractants (Table 1) were added to the swarming plates with the swarming mutants to ascertain whether swarming could be restored, that is, whether mutations that disrupted swarming also affected interkingdom signaling between the bacteria and flies. We chose chemical concentrations of $0.01-0.25 \mathrm{mg} \mathrm{ml}^{-1}$ for our experiments, as these concentrations are close to the physiological concentrations in bacteria and close to the concentrations used to attract flies (Table 1).

The addition of six known fly attractants (putrescine, $\mathrm{NaOH}, \mathrm{KOH}, \mathrm{NH}_{3}$, phenol and lactic acid) restored the swarming motility of different swarming-deficient mutants (Figure 3). Hence, in addition to attracting flies, these chemicals also function as molecules that control swarming of $P$. mirabilis. With the exception of putrescine (Sturgill and Rather, 2004), these fly attractants have not been previously associated with swarming. We also identified seven (RfaL, UreR, Fis, HybG, ZapB, FadE and PROSTU_03490) biochemical pathways through which these attractants work by identifying the genes disrupted by the transposon mutagenesis. Notably, the rfaL mutant (Figure 3, Supplementary Table 1) had increased motility upon adding $\mathrm{NaOH}, \mathrm{KOH}$, putrescine and ammonia, whereas the mutant without chemical addition did not swarm. Moreover, the ureR mutant had up to a 3.6-fold increase in swarming motility upon the addition of ammonia compared with the water control. The full motility complementation results are listed in Supplementary Tables 1, 2, and 3.

RfaL is required for fly attraction and oviposition Initial tests for fly attraction and oviposition were performed with the $r f a L$ mutant versus the wild-type 


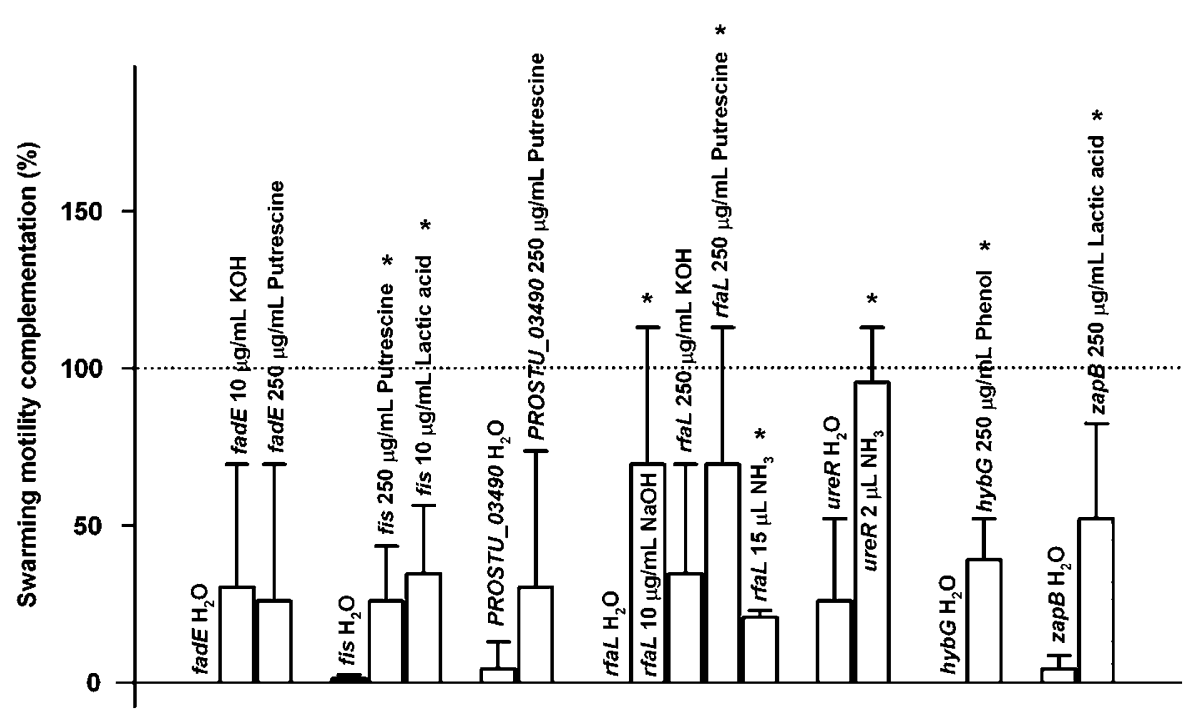

Figure 3 Six fly attractants complement the swarming motility of the swarming-deficient mutants. The degree of complementation is determined by comparing the swarming motility of the mutant with the attractant relative to the wild type with $\mathrm{H}_{2} \mathrm{O}$ added. The symbol '*' indicates statistically significant differences with the control sample $\left(\mathrm{H}_{2} \mathrm{O}\right.$ added $)$ as determined by a Student's $t$-test $(P<0.05)$. Error bars indicate the s.d. of at least three independent cultures.

strain, as the rfaL mutant has complemented swarming motility with the addition of known signaling molecule putrescine (Figure 3, Supplementary Table 1 ). Nine trials examining $L$. sericata attraction (total of 2592 flies) and six trials for oviposition (total of 1138 flies) were conducted. When pooling all individuals as one group, L. sericata had a significantly $\left(G_{\mathrm{P}}=78.11, \mathrm{df}=8\right.$, $P<0.0001)$ greater attraction $(38 \%$ greater $)$ to the wild-type than the rfaL mutant. A breakdown based on sex and ovarian status yielded similar results, as significantly greater attraction for flies to the wildtype versus the rfaL mutant was determined for males $\left(G_{\mathrm{P}}=11.89, \quad \mathrm{df}=8, \quad P<0.0001\right), \quad$ gravid $\left(G_{\mathrm{P}}=8.05, \mathrm{df}=8, P<0.0001\right)$ and nongravid females $\left(G_{\mathrm{P}}=6.51, \mathrm{df}=8, P<0.0001\right)$. Similar results were determined for the oviposition assay with flies depositing significantly $\left(G_{\mathrm{P}}=473.09, \quad \mathrm{df}=5\right.$, $P<0.0001)$ more eggs (63\% more) on the wild-type versus the rfaL mutant. Therefore, RfaL is important for fly attraction and oviposition; it is necessary for swarming, and this swarming deficiency may be complemented by the addition of the known fly attractant putrescine. Hence, putrescine may be an interkingdom signal for this insect.

\section{Putrescine attracts L. sericata}

The compounds indicated as fly attractants in Table 1 have been studied by others for decades (Dethier, 1947; Hilker and Meiners, 2002), for example, Urech et al. (2004) showed that $10-100 \mathrm{mg} \mathrm{ml}^{-1}$ indole can be used together with 2-mercaptoethanol and sodium sulfide as mixtures for attracting $L$. cuprina. In addition, $41 \mathrm{mg} \mathrm{m}^{-1}$ indole, $41 \mathrm{mg} \mathrm{ml}^{-1}$ benzoic acid and $41 \mathrm{mg} \mathrm{ml}^{-1}$ phenol are components of swormlure-2, which is attractive to L. cuprina and Chrysomya spp.
In addition, $200 \mathrm{mg} \mathrm{ml}^{-1} \mathrm{NaOH}$ in water and $7.2-240 \mathrm{mg} \mathrm{ml}^{-1} \mathrm{KOH}$ in water are attractive to L. cuprina, although the mechanism for how flies sense these nonvolatile chemicals is unknown (Hepburn and Nolte, 1943). Furthermore, 0.001$1 \mathrm{mg} \mathrm{ml}^{-1}$ putrescine in water was used to attract the Mexican fruit fly Anastrepha ludens (Robacker, 2001). Here, we verified the response of $L$. sericata to putrescine, as it was the most important compound for complementing the swarming mutations of $P$. mirabilis and found the fly response level was $70 \%$ to $1 \mu \mathrm{g}$.

\section{Discussion}

P. mirabilis is a Gram-negative urinary tract pathogen for humans (Morgenstein et al., 2010). The prominent feature of this bacterium is its ability to swarm. The swarming behavior involves a complex repeating cycle of differentiation between two cell types, the vegetative (swimmer) and swarmer cells (Janda and Abbott, 2005). The swimmer cells dominate in liquid and change into swarmer cells with longer cell length and more flagella after $3-4 \mathrm{~h}$ when they are placed on solid surfaces (Morgenstein et al., 2010). The flagellar rotation is inhibited during this conversion, and an extracellular signal is required to control this multicellular behavior. Proteins related to lipopolysaccharide, flagella, cell wall synthesis, cell division, proteolysis (Belas et al., 1995) and pathogenicity (for example, hemolysin, protease and urease; Liaw et al., 2001) are involved in this conversion. Hence, swarming is related to the pathogenicity of $P$. mirabilis as well as to QS.

In this study, we identified six chemicals (putrescine, $\mathrm{NaOH}, \mathrm{KOH}, \mathrm{NH}_{3}$, phenol and lactic 
acid) that are important for restoring swarming in seven mutants (rfaL, ureR, fis, hybG, zapB, fadE and PROSTU_03490). All the chemicals except putrescine have not been associated with swarming previously, and all but the rfaL mutation have not been associated with swarming previously; hence, putrescine and the rfaL mutation confirm the effectiveness of our approach. Putrescine is an extracellular signal required for swarming in P. mirabilis (Sturgill and Rather, 2004). It belongs to the group of polyamines, including putrescine, agmatine and spermidine, and is a constituent of the outer membrane of $P$. mirabilis. Putrescine is the product of SpeB in P. mirabilis (Sturgill and Rather, 2004), and mutations in spe $A$ (encoding arginine decarboxylase) or spe $B$ (encoding agmatine ureohydrolase) block putrescine production and result in a 2- to 3-h delay in swarmer cell differentiation (Stevenson and Rather, 2006). Adding $25 \mu \mathrm{M}$ exogenous putrescine can completely restore the swarmer cell differentiation of the speA mutant (Stevenson and Rather, 2006). Furthermore, putrescine attracts blow flies (Wardle, 1921) and the Mexican fruit fly (Robacker, 2001).

RfaL (WaaL) is the lipopolysaccharide O-antigen ligase. In P. mirabilis, the deletion of rfaL causes reduced differentiation into swarmer cells primarily due to its repression of the flhDC operon (Morgenstein et al., 2010). In $P$. aeruginosa, the RfaL protein is a membrane protein with 11 potential transmembrane segments (Abeyrathne and Lam, 2007). We show for the first time that putrescine can restore the swarming of an $r f a L$ mutant. In addition, we show the deletion of $r f a L$ decreases fly attraction. Hence, although speculative, it appears RfaL might work as a transporter for putrescine and that putrescine might be an interkingdom signal that is sensed by both blow flies and bacteria. In addition, another O-antigen related gene, rfaD (waaD), is required for swarming motility in $P$. mirabilis (Belas et al., 1995).

Mechanisms used by arthropods to locate resources vital for their reproduction have been widely investigated (Eisemann and Rice, 1987; Eisemann, 1988; Easton and Feir, 1991; Thomas, 1991; Tessmer et al., 1995). In the case of blow flies, volatile organic compounds released by bacteria are the primary mechanism governing their attraction, acceptance and colonization of such resources (Eisemann and Rice, 1987; Chaudhury et al., 2002, 2010; Morris, 2005). However, no one has demonstrated the role of these volatile compounds in the ecology of the bacteria from which they are released. Our results provide insights into this ecology of insects in that we show that known attractants of flies (putrescine, $\mathrm{NaOH}, \mathrm{KOH}, \mathrm{NH}_{3}$, phenol and lactic acid) restore swarming behavior in of our mutated strains of $P$. mirabilis; hence, we link fly attraction with bacterial swarming. Our discovery is of ecological relevance, as it represents a new facet of trophic interactions between resources and those entities competing, or collaborating, to consume them. Therefore, swarming molecules could be regulating entire ecosystem processes and interkingdom communication.

Understanding insect signaling is important in fields ranging from agriculture to human health, as arthropods are the source of much benefit and loss. For example, scolytid bark beetles (Coleoptera: Scolytidae) respond to volatile emissions from their fungal food (Paine et al., 1997), and parasitoids of these beetles also respond to these volatiles (Stephen et al., 1993). Moreover, the sites that attract mosquitoes (Diptera: Culicidae) are governed by a range of cues including volatiles emitted by the bacteria residing on our skin (Bernier et al., 2000) as well as from oviposition sites (Ponnusamy et al., 2008). Indole, which is a quorum-sensing molecule (Lee et al., 2007), has also been isolated from human skin and elicits a strong response by mosquitoes (Pelletier et al., 2010). Furthermore, plants respond to salivary excretions released by feeding herbivorous arthropods. In many instances, the salivary excretions harbor microbes, including fungi and bacteria (Felton and Tumlinson, 2008). We contend that in each of these examples, the interkingdom signaling occurring within the associated microbial communities serve as a mechanism by which arthropods are able to locate and assess resources for themselves or their offspring.

Ammonia is another important chemical that is proposed to be an interkingdom signal molecule (Hilker and Meiners, 2002). Ammonia is produced by almost all organisms, it is one of the most characteristic odors in fresh manure (Richardson, 1916), and it can attract L. sericata adults (Hilker and Meiners, 2002). Urease catalyzes the hydrolysis of urea into carbon dioxide and ammonia (Nicholson et al., 1993), and in P. mirabilis, urease is encoded by the ure operon that contains eight genes. UreR is the transcription regulator of $P$. mirabilis urease. The activation of urease leads to an increase of $\mathrm{pH}$ and the formation of urinary stones; hence, urease is a virulence factor (Mobley and Belas, 1995). Here, we show for the first time that ammonia can complement the swarming deficiency of the ureR mutant. We also propose for the first time that ammonia may be an interkingdom signal that controls both blow fly and bacteria activity.

We also show here that $P$. mirabilis attracts $L$. sericata adults and induces a greater incidence of oviposition, confirming previous observations about bacterial volatiles and their attraction of blow flies (Dethier, 1947). What is novel here is that mutation of one gene in the $P$. mirabilis genome can alter responses of $L$. sericata adults to the wild-type strain significantly. This attraction shift was not complete; however, this lack of universal preference is not a complete surprise. Traits such as orientation and oviposition are very complex behaviors, which are subject to the influences of multiple genetic and environmental factors (Ewing and Manning, 1967; 
Sambandan et al., 2008; Miller et al., 2011). Accordingly, environmental differences among experimental replicates (that is, subtle changes in microbial concentrations, fly density or temperature) may have influenced differences among replicates. For example, the 24-h long period of exposure may have saturated the cage for the attractant odors, rendering the flies incapable of choosing between the strains after a certain period of exposure. Future studies will be performed with tighter temporal resolution that may resolve this potential issue.

There is ample evidence that flies harbor a great deal of genetic variation for oviposition (Miller et al., 2011) and olfactory preferences (Rollmann et al., 2010). For example, recent work has shown that some Drosophila strains will prefer to lay eggs only on food with yeast on it, whereas others will only lay eggs in substrates where they are absent (Miller et al., 2011). They also prefer oviposition substrates/foods inoculated with certain yeast strains (Vacek et al., 1985; Barker, 1992; Anagnostou et al., 2010), establishing a clear microbial connection to such behaviors in Drosophila. Microbial influences in Drosophila are not limited to yeast (the major protein source for fruit flies). Wolbachia spp. infections can alter attraction to a resource in Drosophila (Panteleev et al., 2007) and in mosquitoes (Wiwatanaratanabutr et al., 2010). Wolbachia and Lactobacillus species have also been shown to affect mating preferences in Drosophila (Miller et al., 2010; Sharon et al., 2010), and Lactobacillus infection status can influence heritability in mating preferences (Sharon et al., 2010). The insectmediated attraction observed here may demonstrate particularly high levels of genetic variation, as many insect-microbe interactions show signs of balancing or diversifying selection (Lazzaro and Clark, 2001; Lazzaro et al., 2004; Lazzaro, 2005; Mackay, 2010). Given these known insect-microbe interactions, it is entirely possible that there is genetic variation in $L$. sericata attraction to P. mirabilis. Taken as a whole, these observations presented here indicate that the attractant properties of $P$. mirabilis are likely the result of complex interactions between Proteus and Lucilia genomes.

\section{Acknowledgements}

We are grateful for the Keio and ASKA strains provided by the Genome Analysis Project in Japan. This work was supported by the NIH (R01 GM089999), Texas AgriLife Research and the Texas A \& M University College of Agriculture and Life Sciences. TKW is the T Michael O’Connor Endowed Professor at Texas A \& M University.

\section{References}

Abeyrathne PD, Lam JS. (2007). WaaL of Pseudomonas aeruginosa utilizes ATP in in vitro ligation of $\mathrm{O}$ antigen onto lipid A-core. Mol Microbiol 65: 1345-1359.

Ahmad A, Broce A, Zurek L. (2006). Evaluation of significance of bacteria in larval development of Cochliomyia macellaria (Diptera: Calliphoridae). J Med Entomol 43: 1129-1133.

Anagnostou C, Dorsch M, Rohlfs M. (2010). Influence of dietary yeasts on Drosophila melanogaster life-history traits. Entomol Exp Appl 136: 1-11.

Atlas RM. (2004). Handbook of Microbiological Media. CRC Press: London.

Baba T, Ara T, Hasegawa M, Takai Y, Okumura Y, Baba M et al. (2006). Construction of Escherichia coli K-12 in-frame, single-gene knockout mutants: the Keio collection. Mol Syst Biol 2: 20060008.

Bansal T, Alaniz RC, Wood TK, Jayaraman A. (2010). The bacterial signal indole increases epithelial-cell tight-junction resistance and attenuates indicators of inflammation. Proc Natl Acad Sci USA 107: 228-233.

Barker JSF. (1992). Genetic variation in cactophilic Drosophila for oviposition on natural yeast substrates. Evolution 46: 1070-1083.

Belas R, Goldman M, Ashliman K. (1995). Genetic analysis of Proteus mirabilis mutants defective in swarmer cell elongation. J Bacteriol 177: 823-828.

Bernier UR, Kline DL, Barnard DR, Schreck CE, Yost RA. (2000). Analysis of human skin emanations by gas chromatography/mass spectrometry.2. Identification of volatile compounds that are candidate attractants for the yellow fever mosquito (Aedes aegypti). Anal Chem 72: 747-756.

Broce AB. (1980). Sexual behavior of screwworm flies stimulated by swormlure-2. Ann Entomol Soc Amer 73: 386-389.

Campbell 3rd PW, Phillips 3rd JA, Heidecker GJ, Krishnamani MR, Zahorchak R, Stull TL. (1995). Detection of Pseudomonas (Burkholderia) cepacia using PCR. Pediatr Pulmonol 20: 44-49.

Chaudhury MF, Skoda SR, Sagel A, Welch JB. (2010). Volatiles emitted from eight wound-isolated bacteria differentially attract gravid screwworms (Diptera: Calliphoridae) to oviposit. J Med Entomol 47: 349-354.

Chaudhury MF, Welch JB, Alvarez LA. (2002). Response of fertile and sterile screwworm (Diptera: Calliphoridae) flies to bovine blood inoculated with bacteria originating from screwworm infested animal wounds. J Med Entomol 39: 130-134.

Clark K, Evans L, Wall R. (2006). Growth rates of the blowfly, Lucilia sericata, on different body tissues. Forensic Sci Int 156: 145-149.

Clemmer KM, Rather PN. (2007). Regulation of flhDC expression in Proteus mirabilis. Res Microbiol 158: 295-302.

Cragg JB. (1950). The reactions of Lucilia sericata (Mg.) to various substances placed on sheep. Parasitology 40: 179-186.

Daniels R, Vanderleyden J, Michiels J. (2004). Quorum sensing and swarming migration in bacteria. FEMS Microbiol Rev 28: 261-289.

Davies DG, Parsek MR, Pearson JP, Iglewski BH, Costerton JW, Greenberg EP. (1998). The involvement of cell-tocell signals in the development of a bacterial biofilm. Science 280: 295-298.

Dethier VG. (1947). Chemical Insect Attractants and Repellents. The Blakiston Company: Philadelphia.

Domka J, Lee J, Wood TK. (2006). YliH (BssR) and YceP (BssS) regulate Escherichia coli K-12 biofilm 
formation by influencing cell signaling. Appl Environ Microbiol 72: 2449-2459.

Easton C, Feir D. (1991). Factors affecting the oviposition of Phaenicia sericata (Meigen) (Diptera: Calliphoridae). J Kans Entomol Soc 64: 287-294.

Eisemann CH. (1988). Upwind flight by gravid Australian sheep blowflies, Lucilia cuprina (Wiedemann) (Diptera: Calliphoridae), in response to stimuli from sheep. Bull Entomol Res 78: 273-279.

Eisemann CH, Rice MJ. (1987). The origin of sheep blowfly, Lucilia cuprina (Wiedemann) (Diptera: Calliphoridae), attractants in media infested with larvae. Bull Entomol Res 77: 287-294.

Erdmann GR. (1987). Antibacterial action of myiasiscausing flies. Parasitol Today 3: 214-216.

Ewing AW, Manning A. (1967). The evolution and genetics of insect behaviour. Annu Rev Entomol 12: 471-494.

Felton GW, Tumlinson JH. (2008). Plant-insect dialogs: complex interactions at the plant-insect interface. Curr Opin Plant Biol 11: 457-463.

FoodNet, June 2006. CDC FoodNet Surveillance Report for 2004.

Fraser GM, Bennett JC, Hughes C. (1999). Substratespecific binding of hook-associated proteins by FlgN and FliT, putative chaperones for flagellum assembly. Mol Microbiol 32: 569-580.

González Barrios AF, Zuo R, Hashimoto Y, Yang L, Bentley WE, Wood TK. (2006). Autoinducer 2 controls biofilm formation in Escherichia coli through a novel motility quorum-sensing regulator (MqsR, B3022). J Bacteriol 188: 305-316.

Gram L, Nys Rd, Maximilien R, Givskov M, Steinberg P, Kjelleberg S. (1996). Inhibitory effects of secondary metabolites from the red alga Delisea pulchra on swarming motility of Proteus mirabilis. Appl Environ Microbiol 62: 4284-4287.

Greenberg B. (1973). Biology and Disease Transmission Vol 2. Princeton University Press: Princeton, New Jersey.

Han TH, Lee JH, Cho MH, Wood TK, Lee J. (2010). Environmental factors affecting indole production in Escherichia coli. Res Microbiol 162: 108-116.

Hepburn GA, Nolte MCA. (1943). Sheep blowfly research III. studies on the olfactory reactions of sheep blowflies. Onderstepoort J Vet Res 18: 27-48.

Hilker M, Meiners T. (2002). Chemoecology of Insect Eggs and Egg Decomposition. Blackwell Publishing Company: Berlin.

Hughes DT, Sperandio V. (2008). Inter-kingdom signalling: communication between bacteria and their hosts. Nat Rev Microbiol 6: 111-120.

Izard D, Husson MO, Vincent P, Leclerc H, Monget D, Boeufgras JM. (1984). Evaluation of the four-hour rapid $20 \mathrm{E}$ system for identification of members of the family Enterobacteriaceae. J Clin Microbiol 20: 51-54.

Janda JM, Abbott SL. (2005). The Enterobacteria. ASM press: Washington, DC.

Jayaraman A, Wood TK. (2008). Bacterial quorum sensing: signals, circuits, and implications for biofilms and disease. Annu Rev Biomed Eng 10: 145-167.

Juárez Tomás MS, Ocaña VS, Wiese B, Nader-Macías ME. (2003). Growth and lactic acid production by vaginal Lactobacillus acidophilus CRL 1259, and inhibition of uropathogenic Escherichia coli. J Med Microbiol 52: 1117-1124.

Kobayashi D, Sakata T. (2006). Influence of temperature on short-chain fatty acid production by pig cecal bacteria in vitro. J Nutr Sci Vitaminol 52: 66-69.
Lazzaro BP. (2005). Elevated polymorphism and divergence in the class $\mathrm{C}$ scavenger receptors of Drosophila melanogaster and D. simulans. Genetics 169: 2023-2034.

Lazzaro BP, Clark AG. (2001). Evidence for recurrent paralogous gene conversion and exceptional allelic divergence in the attacin genes of Drosophila melanogaster. Genetics 159: 659-671.

Lazzaro BP, Sceurman BK, Clark AG. (2004). Genetic basis of natural variation in $D$. melanogaster antibacterial immunity. Science 303: 1873-1876.

Lee J, Attila C, Cirillo SL, Cirillo JD, Wood TK. (2009). Indole and 7-hydroxyindole diminish Pseudomonas aeruginosa virulence. Microb Biotechnol 2: 75-90.

Lee J, Bansal T, Jayaraman A, Bentley WE, Wood TK. (2007). Enterohemorrhagic Escherichia coli biofilms are inhibited by 7-hydroxyindole and stimulated by isatin. Appl Environ Microbiol 73: 4100-4109.

Liaw SJ, Lai HC, Ho SW, Luh KT, Wang WB. (2001). Characterisation of $p$-nitrophenylglycerol-resistant Proteus mirabilis super-swarming mutants. J Med Microbiol 50: 1039-1048.

Liberati NT, Urbach JM, Miyata S, Lee DG, Drenkard E, Wu $\mathrm{G}$ et al. (2006). An ordered, nonredundant library of Pseudomonas aeruginosa strain PA14 transposon insertion mutants. Proc Natl Acad Sci USA 103: 2833-2838.

Liu D. (2010). Molecular Detection of Foodborne Pathogens. CRC Press: Boca Raton.

Mackay TF. (2010). Mutations and quantitative genetic variation: lessons from Drosophila. Philos Trans $R$ Soc Lond B Biol Sci 365: 1229-1239.

Margolies DC, Sabelis MW, Boyer JE. (1997). Response of a phytoseiid predator to herbivore-induced plant volatiles: selection on attraction and effect on prey exploitation. J Insect Behav 10: 695-709.

Miller MB, Bassler BL. (2001). Quorum sensing in bacteria. Annu Rev Microbiol 55: 165-199.

Miller PM, Saltz JB, Cochrane VA, Marcinkowski CM, Mobin R, Turner TL. (2011). Natural variation in decision-making behavior in Drosophila melanogaster. PLoS One 6: e16436.

Miller WJ, Ehrman L, Schneider D. (2010). Infectious speciation revisited: impact of symbiont-depletion on female fitness and mating behavior of Drosophila paulistorum. PLoS Pathog 6: e1001214.

Mobley HL, Belas R. (1995). Swarming and pathogenicity of Proteus mirabilis in the urinary tract. Trends Microbiol 3: 280-284.

Moreno LI, Mills D, Fetscher J, John-Williams K, Meadows-Jantz L, McCord B. (2011). The application of amplicon length heterogeneity PCR (LH-PCR) for monitoring the dynamics of soil microbial communities associated with cadaver decomposition. J Microbiol Methods 84: 388-393.

Morgenstein RM, Clemmer KM, Rather PN. (2010). Loss of the WaaL O-antigen ligase prevents surface activation of the flagellar gene cascade in Proteus mirabilis. J Bacteriol 192: 3213-3221.

Morris MC. (2005). Tests on a new bait for flies (Diptera: Calliphoridae) causing cutaneous myiasis (flystrike) in sheep. New Zeal J Agr Res 48: 151-156.

Mulla MS, Axelrod H, Hwang Y-S. (1984). Field evaluation of chemical attractants against the fly Fannia femoralis. J Chem Ecol 10: 349-360.

Nicholson EB, Concaugh EA, Foxall PA, Island MD, Mobley HL. (1993). Proteus mirabilis urease: transcriptional regulation by UreR. J Bacteriol 175: 465-473. 
Paine TD, Raffa KF, Harrigton TC. (1997). Interactions among scolytid bark beetles, their associated fungi, and live host conifers. Annu Rev Entomol 42: 179-206.

Panteleev DY, Goryacheva II, Andrianov BV, Reznik NL, Lazebny OE, Kulikov AM. (2007). The endosymbiotic bacterium Wolbachia enhances the nonspecific resistance to insect pathogens and alters behavior of Drosophila melanogaster. Russ J Genet 43: 1066-1069.

Patel NJ, Zaborina O, Wu L, Wang Y, Wolfgeher DJ, Valuckaite $\mathrm{V}$ et al. (2007). Recognition of intestinal epithelial HIF-1 $\alpha$ activation by Pseudomonas aeruginosa. Am J Physiol Gastrointest Liver Physiol 292: G134-G142.

Pelletier J, Hughes DT, Luetje CW, Leal WS. (2010). An odorant receptor from the southern house mosquito Culex pipiens quinquefasciatus sensitive to oviposition attractants. PLoS One 5: e10090.

Ponnusamy L, Xu N, Nojima S, Wesson DM, Schal C, Apperson CS. (2008). Identification of bacteria and bacteria-associated chemical cues that mediate oviposition site preferences by Aedes aegypti. Proc Natl Acad Sci USA 105: 9262-9267.

Poonam S, Paily KP, Balaraman K. (2002). Oviposition attractancy of bacterial culture filtrates- response of Culex quinquefasciatus. Mem Inst Oswaldo Cruz 97: 359-362.

Ren D, Sims JJ, Wood TK. (2001). Inhibition of biofilm formation and swarming of Escherichia coli by (5Z)-4bromo-5-(bromomethylene)-3-butyl-2(5H)-furanone. Environ Microbiol 3: 731-736.

Richardson OH. (1916). A chemotropic response of the house fly (Musca domestica L). Science 43: 613-616.

Robacker DC. (2001). Roles of putrescine and 1-pyrroline in attractiveness of technical-grade putrescine to the Mexican fruit fly (Diptera: Tephritidae). Fla Entomol 84: 679-685.

Rollmann SM, Wang P, Date P, West SA, Mackay TF, Anholt RR. (2010). Odorant receptor polymorphisms and natural variation in olfactory behavior in Drosophila melanogaster. Genetics 186: 687-697.

Sambandan D, Carbone MA, Anholt RR, Mackay TF. (2008). Phenotypic plasticity and genotype by environment interaction for olfactory behavior in Drosophila melanogaster. Genetics 179: 1079-1088.

Sanderson MW, Sargeant JM, Shi X, Nagaraja TG, Zurek L, Alam MJ. (2006). Longitudinal emergence and distribution of Escherichia coli 0157 genotypes in a beef feedlot. Appl Environ Microbiol 72: 7614-7619.

Schmidtchen A, Wolff H, Rydengard V, Hansson C. (2003). Detection of serine proteases secreted by Lucilia sericata in vitro and during treatment of a chronic leg ulcer. Acta Derm Venereol 83: 310-311.

Sharon G, Segal D, Ringo JM, Hefetz A, Zilber-Rosenberg I, Rosenberg E. (2010). Commensal bacteria play a role in mating preference of Drosophila melanogaster. Proc Natl Acad Sci USA 107: 20051-20056.

Smith CN, Smith N, Gouck HK, Weidhaas DE, Gilbert IH, Mayer MS et al. (1970). L-lactic acid as a factor in the attraction of Aedes aegypti (Diptera: Culicidae) to human hosts. Ann Entomol Soc Am 63: 760-770.

Sokal RR, Rohlf FJ. (1995). Biometry: The Principles and Practice of Statistics in Biological Research. W. H. Freeman and Co.: New York.
Stephen FM, Berisford CW, Dahlsten DL, Fenn P, Moser JC. (1993). Invertebrate and microbial associates. In: Schowalter TD, Filip GM (eds). Beetle-Pathogen Interactions in Conifer Forests. Academic Press: San Diego, pp 129-153.

Stevenson LG, Rather PN. (2006). A novel gene involved in regulating the flagellar gene cascade in Proteus mirabilis. J Bacteriol 188: 7830-7839.

Sturgill G, Rather PN. (2004). Evidence that putrescine acts as an extracellular signal required for swarming in Proteus mirabilis. Mol Microbiol 51: 437-446.

Tarone AM, Picard CJ, Spiegelman C, Foran DR. (2011). Population and temperature effects on Lucilia sericata (Diptera: Calliphoridae) body size and minimum development Time. J Med Entomol 48: 1062-1068.

Tessmer JW, Meek CL, Wright VL. (1995). Circadian patterns of oviposition by necrophilous flies (Diptera: Calliphoridae) in southern Louisiana. Southwest Entomol 20: 439-445.

Thomas DB. (1991). Time-activity budget of adult screwworm behavior (Diptera: Calliphoridae). J Med Entomol 28: 372-377.

Ueda A, Wood TK. (2009). Connecting quorum sensing, c-di-GMP, pel polysaccharide, and biofilm formation in Pseudomonas aeruginosa through tyrosine phosphatase TpbA (PA3885). PLoS Pathog 5: e1000483.

Updegraff DM. (1949). The production of phenol and para-cresol by marine bacteria. J Bacteriol 57: 555-564.

Urech R, Green PE, Rice MJ, Brown GW, Duncalfe F, Webb P. (2004). Composition of chemical attractants affects trap catches of the Australian sheep blowfly, Lucilia cuprina, and other blowflies. J Chem Ecol 30: 851-866.

Vacek DC, East PD, Barker JSF, Soliman MH. (1985). Feeding and oviposition preferences of Drosophila buzzatii for microbial species isolated from its natural environment. Biol J Linn Soc 24: 175-187.

Vince A, Dawson AM, Park N, O’Grady F. (1973). Ammonia production by intestinal bacteria. Gut 14: 171-177.

Walker KE, Moghaddame-Jafari S, Lockatell CV, Johnson D, Belas R. (1999). ZapA, the IgA-degrading metalloprotease of Proteus mirabilis, is a virulence factor expressed specifically in swarmer cells. Mol Microbiol 32: 825-836.

Wardle RA. (1921). The protection of meat commodities against blowflies. Ann Appl Biol 8: 1-9.

Waters CM, Bassler BL. (2005). Quorum sensing: cell-tocell communication in bacteria. Annu Rev Cell Dev Biol 21: 319-346.

Wiwatanaratanabutr I, Allan S, Linthicum K, Kittayapong P. (2010). Strain-specific differences in mating, oviposition, and host-seeking behavior between Wolbachiainfected and uninfected Aedes albopictus. J Am Mosq Control Assoc 26: 265-273.

Wu L, Estrada O, Zaborina O, Bains M, Shen L, Kohler JE et al. (2005). Recognition of host immune activation by Pseudomonas aeruginosa. Science 309: $774-777$.

Yokoyama MT, Carlson JR. (1981). Production of skatole and para-cresol by a rumen Lactobacillus sp. Appl Environ Microbiol 41: 71-76.

Supplementary Information accompanies the paper on The ISME Journal website (http://www.nature.com/ismej) 